SAINS TANAH - Journal of Soil Science and Agroclimatology

Journal homepage: http://jurnal.uns.ac.id/tanah

\title{
Effects of various irrigation and fertilizer on water efficiency and tomato yield (Solanum lycopersicum) in Alfisols
}

\author{
Rahayu $^{1 *}$, Aktavia Herawati ${ }^{1}$, Nur Faizaturrohmah ${ }^{2}$ \\ ${ }^{1}$ Department of Soil Science, Faculty of Agriculture, Sebelas Maret University, Indonesia \\ ${ }^{2}$ Undergraduate Program of Soil Science, Faculty of Agriculture, Sebelas Maret University, Indonesia
}

\begin{tabular}{|c|c|}
\hline ARTICLE INFO & ABSTRACT \\
\hline Keywords: & Investing in irrigation is very important and strategic in the context of water supply for \\
\hline Drip irrigation & agriculture. Therefore, this study aims to identify the most efficient irrigation technique \\
\hline Inorganic fertilizer & and type of fertilizer to maximize the yield of tomatoes (Solanum lycopersicum) in Alfisols. \\
\hline Manual irrigation & This study was a greenhouse pot experiment with a factorial completely randomized \\
\hline Organic fertilizer & design with two factors consisting of four irrigation techniques (pottery, drip, $75 \%$ ETc \\
\hline Pottery & $\begin{array}{l}\text { manual, and } 100 \% \text { ETc manual) and types of fertilizers (without, organic, inorganic, mixed } \\
\text { fertilizer). The results showed that pottery irrigation had the highest Nitrogen content in }\end{array}$ \\
\hline Article history & the soil and saved up to $50 \%$ water compared to $100 \%$ ETc. On the other hand, drip \\
\hline Submitted: 2020-11-19 & irrigation uses water of $75 \%$ ETc with similar plant yield results. The pottery irrigation was \\
\hline Accepted: 2021-12-08 & the most efficient irrigation method for growing tomato than $75 \%$ ETc manual irrigation, \\
\hline $\begin{array}{l}\text { Available online: } 2021-12-29 \\
\text { Published regularly: December }\end{array}$ & $\begin{array}{l}\text { and } 100 \% \text { ETc manual irrigation with mixed fertilizers (I4P3) was the highest on tomato } \\
\text { vield. }\end{array}$ \\
\hline
\end{tabular}

2021

* Corresponding Author

Email address:

rahayu_pn@staff.uns.ac.id

How to Cite: Rahayu, Herawati, A., Faizaturrohmah, N. (2021). Effects of various irrigation and fertilizer on water efficiency and tomato yield (Solanum lycopersicum) in Alfisols. Sains Tanah Journal of Soil Science and Agroclimatology, 18(2): 152158. https://dx.doi.org/10.20961/stjssa.v18i2.45788

\section{INTRODUCTION}

The process of selecting an efficient irrigation technique has become important as water scarcity occurs during the dry season, specifically on marginal land. Irrigation provides and regulates water by using surface and groundwater in fulfilling agricultural interests (Adhikary \& Pal, 2020). In contrast to other inputs such as pesticides, which play a limited role in the production process, water is very important in agriculture as it fulfills plants' needs (Ariyanto et al., 2019). Different irrigation methods are currently practiced around the world, such as sprinkler, drip, check basin, furrow, etc. The drip irrigation method was reported as a system in which water and crop water use efficiency are used and examined but required definitions of terms (Nabayi et al., 2018). In subsurface drip irrigation systems, plants are supplied with water directly to the root zone according to their needs. Therefore, drip irrigation is the most efficient method, followed by sprinkler and flood irrigation (Leng et al., 2017).

Drip irrigation is heavily influenced by crop evapotranspiration (ETc) and has little effect on the groundwater table. Furthermore, crop irrigation and fertilization can improve water use efficiency and increase yields (Phuntsho et al., 2011) and nutrient efficiency (Isah et al., 2014). Plants grow better under subsurface drip irrigation than under surface drip irrigation, which is influenced by the crop coefficient factor $(\mathrm{Kc})$. Subsurface irrigation has a higher yield and irrigation water use efficiency than drip irrigation (Martínez \& Reca, 2014). Ceramic pitchers supply water under a negative hydraulic head and eliminate the need for pressurized flow inside the piper (Abu-Zreig et al., 2018). The pottery pot irrigation method is an alternative to the drip method and advancement and effective innovation of localized irrigation methods. It has been shown to be suitable for crop production in areas of water scarcity (Adhikary \& Pal, 2020).

Tomato plants need sufficient water during the transplanting, flowering, and fruit formation phase. The optimum water requirement for tomatoes is approximately $75 \%$ Etc. In the tropical greenhouse, the optimum is 
approximately 4.1 and $5.6 \mathrm{~mm} \mathrm{day}^{-1}$ (Somnuek et al., 2020). Water use efficiency is more sensitive to irrigation than to fertilization (Xiukang \& Yingying, 2016). Irrigation influences many plant attributes of tomato, such as the height of the plant, the number of leaves, the number of branches, etc. Practicing irrigation less on tomatoes often reduces the growth and physiological components but increases fruit quality (Jumawati et al., 2014). Xiukang and Yingying (2016) reported that increasing irrigation level influenced the increase in tomato fruit yield, fertilizer rate, and decreased water use efficiency. Helyes et al. (2012) stated that irrigated plants showed a significantly higher yield of tomatoes, while rainfed plants lost yield, and better water supply caused higher Brix yield than rainfed.

Jumantono sub-district, Karanganyar Region, is dominated by Alfisols, which are relatively recent soils with crystalline, nutrient-rich clay minerals. Alfisol had textures from sand to sandy loam, strong acid to neutral (pH 5.10 to 7.05) (Ajiboye et al., 2019). Furthermore, it has low SOC, total Nitrogen, CEC, available phosphate, exchangeable potassium-calcium (Syamsiyah et al., 2018). Alfisols in the medium rainfall regions has an occurrence of droughts and moisture stress. Therefore, stored runoff water as irrigation during the rainy season is expected to be highly beneficial to the crops (Pathak et al., 2013). Recently, there have been limited land and water resources for the production of sustainable food. With the pressure on the limited freshwater and land resources, sustaining productivity at higher levels will require efficient land and water resources. In dryland areas, the calculation of the amount and time of precipitation is insufficient due to the water requirements of the plants, which can lead to reduced plant productivity (Abegunrin et al., 2020). In this situation, it is important to create efficient irrigation. Therefore, this study aims to achieve the efficient irrigation and yield of tomato (Solanum lycopersicum) in Alfisol through various types of irrigation and fertilizers.

\section{MATERIAL AND METHODS}

The materials used were tomato plant seeds (Solanum lycopersicum), Jumantono's Alfisol soil, and fertilizers. The soil of Jumantono sub-district was dominated by Alfisols, with air temperature averaging about $27.8^{\circ} \mathrm{C}$, average relative humidity of $84 \%$, and average rainfall monthly of $288 \mathrm{~mm}$ (Rahayu, Syamsiyah, et al., 2020). Furthermore, this study was a pot experiment carried out for six months started from July 2019. The experiment was located at the Screen House of field laboratory at Universitas Sebelas Maret in Jumantono subdistrict, Karanganyar Region (737'48' S; $110^{\circ} 56^{\prime} 52^{\prime \prime}$ E). The experiment was arranged using completely randomized with two factors, namely: irrigation and fertilizer, each factor with four treatments, each unit replicated three times. The irrigation treatments were: pottery irrigation (I1), drip irrigation (12), 75\% ETc manual irrigation (I3), and 100\% ETC manual irrigation (14). The fertilizer treatments were: without fertilizer (Po), organic fertilizer @ $0.28 \mathrm{~kg} /$ pot (P1), inorganic fertilizer NPK (16-16-16) @ 0.64 g/pot (P2), and mixed fertilizer (P3).

The pottery originated from ceramics home industry center Bayat in Klaten region (Indonesia), with a volume of 7 liters, clay content of $90 \%$ and very fine sand of $10 \%$, and a Cole value of $<0.03$. The pottery irrigation head served as a water filling hole, which was covered after filling with water. The pottery was buried in the soil of $60 \mathrm{~cm}$ diameter growing media pot and the head were exposed for filling the irrigation water. Water moved through the pottery wall by means of osmosis into the soil due to root and soil matrix adsorption. The pottery was filled with water whenever it became empty during the irrigation season. The amount of water was measured daily by measuring the height level of water in the pottery using a ruler. The drip irrigation system was developed by installing a bottle and an infusion hose, which is hung with a distance of $150 \mathrm{~cm}$ between the water storage container and emitter. The discharge rate of the system was 2.8 liters per day (24 hours). The drip bottle was filled with water whenever it became empty during the irrigation season. Manual irrigation with $75 \%$ and $100 \%$ ETc was performed with a cup and hand-fed into the pot at an amount calculated by the daily reference evapotranspiration (ETo) and Kc (Table 1). The ETo calculation started by calculating the rainfall, wind speed, etc., for the last five years from 2014-2018 and then analyzed using the CROPWAT 8.0 (FAO, 1992). The schematic of pottery and drip irrigation is shown in Figure 1.

In the fertilizer factor, the dose of cow dung as an organic fertilizer (P1) was $0.28 \mathrm{~kg} \mathrm{pot}^{-1}$, the dose of NPK (16-16-16) (P2) was $0.64 \mathrm{~g} \mathrm{pot}^{-1}$, applied in 5 fractions at an interval of 10 days after planting. The dose of mixed fertilizers (P3) was Nitrogen $7.84 \mathrm{~g} \mathrm{pot}^{-1}$; phosphorus $2.12 \mathrm{~g} \mathrm{pot}^{-1}$; potassium 2.3 $\mathrm{g} \mathrm{pot}^{-1}$, and $63.56 \mathrm{~g} \mathrm{pot}^{-1}$ of cow dung applied to each pot. The cow dung contained organic- $\mathrm{C} 22.7 \%, \mathrm{C} / \mathrm{N}$ ratio 8.1 , Nitrogen $2.8 \%, \mathrm{P}_{2} \mathrm{O}_{5} 0.76 \%$, and $\mathrm{K}_{2} \mathrm{O} 0.82 \%$.

Table 1. The evapotranspiration rate and irrigation volume requirement during the experiment (2019)

\begin{tabular}{lcccr}
\hline \multicolumn{1}{c}{ Date } & $\begin{array}{c}\text { ETo } \\
\text { (mm/day) }\end{array}$ & Kc & ETc & $\begin{array}{r}\text { Irrigation } \\
\text { for 100\% } \\
\text { ETc (ml) }\end{array}$ \\
\hline 23-31 July & 3.31 & 0.6 & 1.986 & 390 \\
1-6 August & 3.78 & 0.6 & 2.268 & 445 \\
7-31 August & 3.78 & 0.9 & 3.402 & 668 \\
1-4 September & 4.23 & 0.9 & 3.807 & 747 \\
5-30 September & 4.23 & 1.15 & 4.865 & 955 \\
1-3 October & 4.56 & 1.15 & 5.244 & 1029 \\
4-23 October & 4.56 & 1.0 & 4.560 & 895 \\
\hline
\end{tabular}

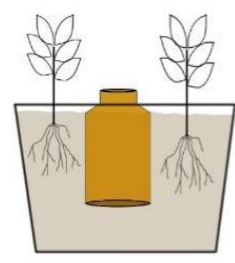

(a)

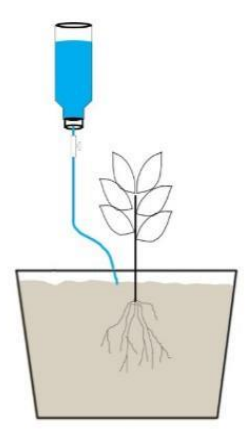

(b)
Figure 1. Schematic of (a) Pottery irrigation and (b) Drip irrigation 
Table 2. Effects of fertilizer on soil properties, water volume for irrigation, and plant growth

\begin{tabular}{|c|c|c|c|c|c|c|c|c|c|c|}
\hline \multirow[b]{2}{*}{ Fertilizer } & \multicolumn{4}{|c|}{ Soil Characteristics } & \multirow[b]{2}{*}{$\begin{array}{l}\text { Water } \\
\text { Volume } \\
\text { (I) }\end{array}$} & \multicolumn{5}{|c|}{ Plant Growth } \\
\hline & $\begin{array}{c}\mathrm{pH} \\
\mathrm{H}_{2} \mathrm{O}\end{array}$ & $\begin{array}{c}\text { Soil } \\
\text { Moisture } \\
\text { Content } \\
(\%)\end{array}$ & $\begin{array}{c}\text { Organic } \\
\text { C }\end{array}$ & $\begin{array}{c}\text { Total N } \\
\text { (\%) }\end{array}$ & & $\begin{array}{l}\text { Plant } \\
\text { height } \\
\text { (cm) }\end{array}$ & $\begin{array}{c}\text { Plant } \\
\text { Fresh } \\
\text { weight } \\
\text { (g) }\end{array}$ & $\begin{array}{c}\text { Fruit } \\
\text { weight } \\
\text { (g) }\end{array}$ & $\begin{array}{l}\text { Root } \\
\text { volume } \\
\text { (ml) }\end{array}$ & $\begin{array}{c}\mathrm{N} \text { in } \\
\text { Plant } \\
\text { Tissue } \\
(\%)\end{array}$ \\
\hline Control & $5.79 \mathrm{a}$ & $23.7 \mathrm{a}$ & $0.41 \mathrm{c}$ & $0.08 \mathrm{c}$ & $247.9 \mathrm{a}$ & $56.7 \mathrm{~b}$ & $140.8 \mathrm{~d}$ & $96.0 \mathrm{c}$ & $20.5 c$ & $0.02 c$ \\
\hline Organic & $5.36 \mathrm{~b}$ & $20.7 \mathrm{~b}$ & $1.37 \mathrm{ab}$ & $0.20 \mathrm{~b}$ & $210.4 \mathrm{~b}$ & $87.1 \mathrm{a}$ & $247.5 \mathrm{c}$ & $740.8 \mathrm{~b}$ & $27.9 b c$ & $0.62 \mathrm{~b}$ \\
\hline Inorganic & $4.81 \mathrm{c}$ & $20.1 \mathrm{~b}$ & 0.88 bc & $0.20 \mathrm{~b}$ & $213.5 \mathrm{~b}$ & $94.0 \mathrm{a}$ & $407.2 \mathrm{~b}$ & $1183.0 \mathrm{a}$ & $37.1 \mathrm{~b}$ & $1.54 \mathrm{a}$ \\
\hline Mixed & $5.24 b$ & $19.6 \mathrm{~b}$ & $1.69 \mathrm{a}$ & $0.33 a$ & $203.8 \mathrm{~b}$ & $87.8 \mathrm{a}$ & $581.0 \mathrm{a}$ & $1316.7 \mathrm{a}$ & $50.0 \mathrm{a}$ & $1.17 \mathrm{a}$ \\
\hline
\end{tabular}

Note: means in a column followed by the same letters show no significant difference with Duncan $5 \%$

The soil type was Alfisol, taken from the topsoil at a depth of 0-30 cm, weighed at $35 \mathrm{~kg}$, and poured into a pot of $60 \mathrm{~cm}$ diameter. The Alfisols was a clay texture, with $81.1 \%$ clay, $3.7 \%$ silt, and $15.3 \%$ sand. The chemical characteristics of the soil are $\mathrm{pH} 6.18$, organic $\mathrm{C}$ content $0.89 \%$, CEC: $26.05 \mathrm{me} \%$, base saturation $36.58 \%$. The soil was air-dried, then weighed and placed in the pot, and fertilized for treatment and irrigation before tomato was planted. Tomato seed was grown in a small polybag and planted into the pot after one month. Tomato plants were cultivated in the form of weed and pest control. The harvest of the fruits was carried out whenever the fruit started to turn red. The final harvest was performed 12 weeks after planting. The data were analyzed by ANOVA and Duncan multi-range test.

\section{RESULTS}

Table 1 showed that plant evapotranspiration (ETc) increased from July to October due to climatic factors and plant growth factors, which is indicated by the increase in ETo. Irrigation water demand increased from $390 \mathrm{ml}$ in July to $1,029 \mathrm{ml}$ in October based on 100\% ETc (Table 1). The growth of tomato plants complemented Kc, ETc increased. The application of inorganic (NPK) fertilizers significantly reduced the soil's $\mathrm{pH}$ value and water content (Table 2). On the other hand, Table 2 showed that fertilization increases organic C, N, plant height, fresh plant weight, fruit weight, root volume, and tissue nitrogen. Applying NPK and mixed fertilizers resulted in a higher fruit weight than the control and organic fertilizers. In addition, the application of mixed fertilizer was the highest root volume. Table 3 showed that the pottery irrigation was the lowest volume water irrigation, soil pH, soil organic C, plant height, and plant fresh weight. Although the pottery irrigation resulted in low plant dry weight and plant height, the use of pots resulted in more fruit weight, root volume, and $\mathrm{N}$ tissue, but not significantly different from other treatments. The highest plant dry and fruit weight was obtained from $100 \%$ ETc manual irrigation. The drip and $75 \%$ ETc manual irrigations were more water-efficient than $100 \%$ ETc irrigation, but both irrigation techniques significantly lower fruit weight compared to pottery and $100 \%$ ETc manual irrigations.

Table 4 showed that the pottery irrigation and fertilization increased plant height, fruit weight, root volume, and $\mathrm{N}$ of plant tissue. Pottery irrigation with a mixed fertilizer (I1P3) reduced irrigation water (Figure 2) but increased soil $\mathrm{N}$, soilmoisture content, organic $\mathrm{C}$, plant height, and root volume (Table 4). In the pottery irrigation, the use of chemical fertilizers increased fresh plant weight, fruit weight, $\mathrm{N}$ in plant tissue, and root volume. Furthermore, in drip irrigation, the applied fertilizer increased soil $\mathrm{N}$ and plant height. In association with NPK fertilizer and mixed fertilizer, this irrigation increased fruits, root volume, and tissue $\mathrm{N}$ (Table 4). However, drip irrigation with fertilizer application did not influence the soil conditions and the root volume of the plant. At $75 \%$ ETc manual irrigation, applying organic fertilizer and mixed fertilizer increased soil $\mathrm{N}$, soil-moisture content, fresh weight plant, fruit weight, and $\mathrm{N}$ tissue. With $75 \% \mathrm{ETC}$ and $100 \%$ ETc manual irrigations, the application of organic fertilizers had no significant influence on soil properties and the yield of tomatoes. With 100\% ETc manual irrigation, the application of NPK fertilizer and mixed fertilizer reduced soil pH but increased soil $\mathrm{N}$, fresh weight, soil-moisture content, plant height, fruit weight, and tissue $\mathrm{N}$ (Table 4). The use of pottery irrigation reduced the amount of water applied compared to drip and two manual irrigations (Table 5).

Table 3. Comparison of mean soil properties applied irrigation volume and plant attributes under different irrigation techniques

\begin{tabular}{|c|c|c|c|c|c|c|c|c|c|c|c|}
\hline \multirow[b]{2}{*}{ Irrigation } & \multicolumn{4}{|c|}{ Soil characteristics } & \multirow[b]{2}{*}{$\begin{array}{l}\text { Water } \\
\text { Volume } \\
\text { (I) }\end{array}$} & \multicolumn{6}{|c|}{ Plant growth } \\
\hline & $\begin{array}{c}\mathrm{pH} \\
\text { (unit) }\end{array}$ & $\begin{array}{c}\text { Soil } \\
\text { moisture } \\
\text { content } \\
(\%)\end{array}$ & $\begin{array}{c}\text { Organic } \\
\text { C (\%) }\end{array}$ & $\begin{array}{l}\text { Total } \\
\text { N (\%) }\end{array}$ & & $\begin{array}{l}\text { Plant } \\
\text { height } \\
(\mathrm{cm})\end{array}$ & $\begin{array}{l}\text { Plant } \\
\text { Fresh } \\
\text { weight } \\
\text { (g) }\end{array}$ & $\begin{array}{c}\text { Plant } \\
\text { dry } \\
\text { weight } \\
\text { (g) }\end{array}$ & $\begin{array}{l}\text { Fruit } \\
\text { weight } \\
\text { (g) }\end{array}$ & $\begin{array}{l}\text { Root } \\
\text { volume } \\
(\mathrm{ml})\end{array}$ & $\begin{array}{c}\mathrm{N} \text { in } \\
\text { plant } \\
\text { tissue } \\
(\%)\end{array}$ \\
\hline Pottery & $5.05 b$ & $21.0 a b$ & $0,096 c$ & $0.22 a$ & $135.4 d$ & $68.5 b$ & $284.3 b$ & $70.25 b$ & $859 a b$ & $41.58 a$ & $0.93 a$ \\
\hline Drip & $5.32 \mathrm{ab}$ & $21.36 a b$ & $0.740 \mathrm{~b}$ & $0.20 a$ & $252.0 \mathrm{~b}$ & $75.8 \mathrm{~b}$ & $346.4 a b$ & 77.1ab & $596 b$ & $31.41 a$ & $0.58 a$ \\
\hline Manual 75\%, & $5.47 a$ & $20.07 a$ & $1.183 a$ & $0.18 a$ & $209.3 c$ & $89.2 a$ & $321.7 b$ & $69.2 b$ & $692 b$ & $31.41 \mathrm{a}$ & $0.97 a$ \\
\hline Manual 100\% & $5.37 a b$ & $21.59 b$ & $1.317 a$ & $0.20 a$ & $279.1 a$ & $92.1 a$ & $424.0 a$ & $90.3 a$ & 1188a & $29.91 a$ & $0.88 a$ \\
\hline
\end{tabular}

Note: Means in a column followed by the same letters show no significant difference in the DMRT test at a $5 \%$ significance level. 

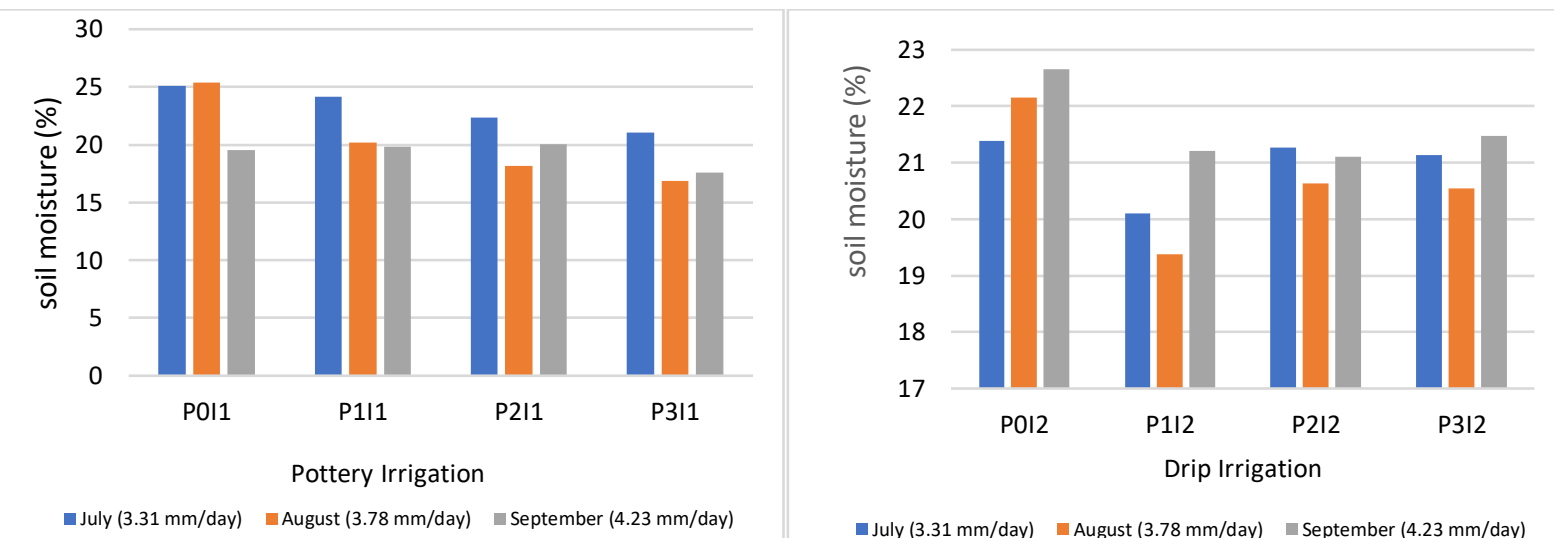

—uly $(3.31 \mathrm{~mm} /$ day) $\square$ August $(3.78 \mathrm{~mm} /$ day $) \quad$ September $(4.23 \mathrm{~mm} /$ day $)$
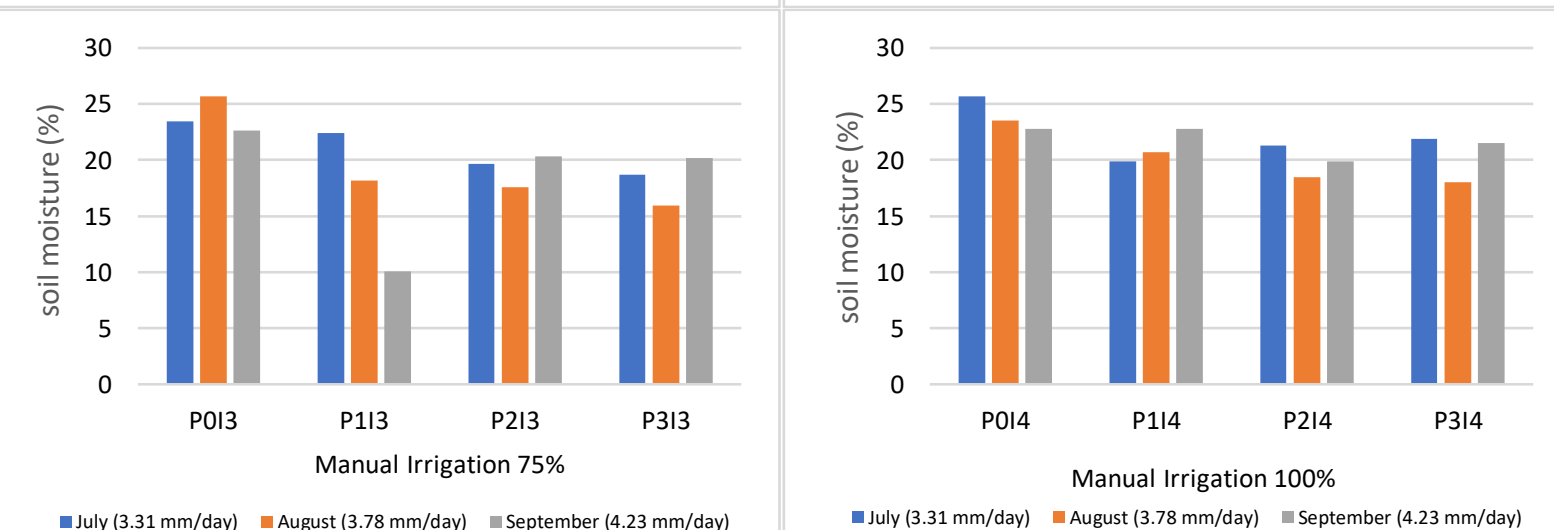

Figure 2. Soil moisture content by several irrigation types: (a) Pottery irrigation, (b) Drip irrigation, (c) Manual 75 \% ETc, (d) Manual $100 \%$ ETc.

Table 5 also showed that drip irrigation needed water as much as $75 \%$ ETc manual irrigation. With the pottery irrigation, the use of organic and chemical fertilizer reduced similar water volume compared to the control, while the use of mixed fertilizer, this irrigation technique is the most waterefficient. Mixed fertilizer in the pottery irrigation treatment showed water efficiency from week 1 to 12 . In the pottery irrigation without fertilizer, the water consumption is similar to the $75 \%$ ETc until week 6 and starts decreasing from week 7 to 12 . Water used for irrigation also showed similar between organic and inorganic fertilizer without mixing. $100 \%$ ETc manual irrigation required more water than the other treatments, while for drip irrigation, $75 \%$ ETC and ETC $100 \%$, the water used was the same for each fertilizer application in the irrigation treatment series. Figure 2 shows that the control had high humidity compared to the other treatments. Pottery irrigation treatment has been demonstrated that soil moisture fluctuates and decreases over time, while the other treatment provides stable water irrigation.

\section{DISCUSSION}

The need for irrigation water increased from $390 \mathrm{ml}$ in July to $1,029 \mathrm{ml}$ in October. The increase in water irrigation from July to October is caused not only by the stage of growth of tomato, but also by the increase in ETo. The drip irrigation used 252 liters of water during the growth of tomato. Therefore, the drip irrigation water usage was higher than required for the $75 \%$ ETc manual irrigation, while the pot irrigation used only 135.4 liters of water. This indicates a subsurface drip irrigation system with $20 \%$ lower water than net irrigation requirements is a good strategy to conserve water and achieve an appropriate level of olive orchard plant production, where the alternative subsurface irrigation method seems to perform better than the drip irrigation (Martínez \& Reca, 2014).

$100 \%$ ETc manual irrigation caused higher soil humidity than 75\% ETc manual irrigation. Martínez and Reca (2014) reported that the subsurface irrigation method could provide higher yield and irrigation efficiency than drip irrigation, which is generally a very efficient irrigation technique (Wang et al., 2011). However, this study shows that the pottery irrigation uses lower water than drip irrigation. This finding agrees with Gebru et al. (2018), which reported that clay pot irrigation technology is a conservation irrigation system that can conserve water when compared to the conventional watering irrigation system. In the pottery system, irrigation water is regularly released into the soil, thus, the soil moisture is always maintained.

Tomato plants had different water requirements at different growth phases, it increases with the advancement of the growth stage, with a maximum value from July to October. During the reproductive growth phase, a sufficient water supply ensures a high biomass yield for soybeans (Cui et al., 2021). In the pottery system, the filling of a pot with water can be adjusted to the conditions of each plan. 
Table 4. Comparison of mean soil properties, applied irrigation volume, and plant attributes under different combinations of irrigation techniques and fertilizer types

\begin{tabular}{|c|c|c|c|c|c|c|c|c|c|c|}
\hline \multirow[b]{2}{*}{ Treatment } & \multicolumn{4}{|c|}{ Soil characteristics } & \multirow[b]{2}{*}{$\begin{array}{l}\text { Water } \\
\text { Volume } \\
\text { (I) }\end{array}$} & \multicolumn{5}{|c|}{ Plant growth } \\
\hline & $\mathrm{pH}$ & $\begin{array}{c}\text { Soil } \\
\text { moisture } \\
\text { content } \\
(\%)\end{array}$ & $\begin{array}{c}\text { Organic } \\
\text { C (\%) }\end{array}$ & $\begin{array}{c}\text { Total N } \\
(\%)\end{array}$ & & $\begin{array}{c}\text { Plant } \\
\text { height } \\
(\mathrm{cm})\end{array}$ & $\begin{array}{l}\text { Plant } \\
\text { fresh } \\
\text { weight } \\
\text { (g) }\end{array}$ & $\begin{array}{c}\text { Fruit } \\
\text { weight } \\
\text { (g) }\end{array}$ & $\begin{array}{l}\text { Root } \\
\text { volume } \\
(\mathrm{ml})\end{array}$ & $\begin{array}{c}\mathrm{N} \\
\text { tissue } \\
(\%)\end{array}$ \\
\hline I1P0 & $5.45 a b c$ & $23.83 a b$ & $0.17 \mathrm{~cd}$ & $0.08 \mathrm{e}$ & $251 a$ & $27 b$ & $139 f$ & $110 \mathrm{e}$ & $18.0 \mathrm{c}$ & $0.02 c$ \\
\hline I1P1 & 5.17abcd & 21.44abcd & 1.50abcd & $0.26 a b c$ & $101 \mathrm{~cd}$ & $72 a$ & 229ef & 910bcd & $31.6 a b c$ & $0.98 a b c$ \\
\hline I1P2 & $4.28 d$ & $20.21 \mathrm{bcd}$ & $0.76 \mathrm{abcd}$ & $0.22 \mathrm{~cd}$ & $113 c$ & $94 a$ & 405bcde & $1367 a b c$ & 53.3ab & $1.59 a$ \\
\hline I1P3 & 5.28abcd & $18.52 d$ & $1.74 a b$ & $0.34 a b$ & $75 d$ & $80 a$ & $363 c d e f$ & $1051 \mathrm{bcd}$ & $63.3 a$ & $1.11 \mathrm{abc}$ \\
\hline I2P0 & $5.54 a b c$ & $23.22 \mathrm{ab}$ & $0.14 d$ & $0.07 e$ & $252 a$ & $29 b$ & $148 f$ & $151 \mathrm{e}$ & $19.0 c$ & $0.01 c$ \\
\hline I2P1 & $5.32 \mathrm{abc}$ & $20.19 b c d$ & $1.44 a b c d$ & $0.22 \mathrm{~cd}$ & $252 a$ & $88 a$ & 233ef & 489cde & $25.0 b c$ & $0.11 b c$ \\
\hline 12P2 & $5.06 \mathrm{bcd}$ & 21.01abcd & 1.12abcd & $0.23 \mathrm{bcd}$ & $252 a$ & $94 a$ & 406bcde & $1044 \mathrm{bcd}$ & $36.6 a b c$ & $1.68 a$ \\
\hline 12P3 & $5.35 a b c$ & $21.04 a b c d$ & $1.66 \mathrm{abc}$ & $0.28 \mathrm{abc}$ & $252 a$ & $92 a$ & $598 a b$ & $798 b c d$ & $45.0 \mathrm{abc}$ & $0.45 a b c$ \\
\hline I3PO & 5.98ab & 22.72abc & $0.17 \mathrm{~cd}$ & $0.08 \mathrm{e}$ & $209 b$ & $79 a$ & $136 f$ & 111de & $22.0 \mathrm{bc}$ & $0.02 c$ \\
\hline |3P1 & $5.44 a b c$ & $20.21 \mathrm{bcd}$ & 1.09abcd & $0.18 \mathrm{cde}$ & $209 b$ & $97,67 a$ & 231ef & 576bcde & $28.3 b c$ & $0.87 a b c$ \\
\hline 13P2 & 5.25abcd & $19.14 \mathrm{~cd}$ & 1.14abcd & $0.12 \mathrm{de}$ & $209 b$ & $91 a$ & 334,3def & $766 \mathrm{bcd}$ & $30.0 b c$ & $1.54 a$ \\
\hline 13P3 & 5.21abcd & $18.21 \mathrm{~d}$ & $1.20 \mathrm{abcd}$ & $0.36 a$ & $209 b$ & $89 a$ & $585,3 a b c$ & $1316 a b c$ & $50.0 \mathrm{abc}$ & $1.45 a b$ \\
\hline I4P0 & $6.20 a$ & $24.95 a$ & $0.24 b c d$ & $0.09 \mathrm{e}$ & $279 a$ & $91 a$ & $140 f$ & 112de & $23.0 \mathrm{bc}$ & $0.11 \mathrm{c}$ \\
\hline |4P1 & $5.51 \mathrm{abc}$ & 21.09abcd & 1.44abcd & $0.13 \mathrm{de}$ & $279 a$ & $91 a$ & 296def & $986 b c d$ & $26.6 b c$ & $0.48 a b c$ \\
\hline 14P2 & $4.66 \mathrm{~cd}$ & $19.89 \mathrm{bcd}$ & $0.48 \mathrm{bcd}$ & $0.22 \mathrm{~cd}$ & $279 a$ & $96 a$ & $482 \mathrm{bcd}$ & 1533ab & $28.3 b c$ & $1.35 a b$ \\
\hline 14P3 & $5.10 \mathrm{bcd}$ & $20.45 \mathrm{bcd}$ & $2.13 a$ & $0.37 a$ & $279 a$ & $90 a$ & $777 a$ & $2100 a$ & $41.6 a b c$ & $1.66 \mathrm{a}$ \\
\hline
\end{tabular}

Note: Means in a column followed by the same letters show no significant difference in the DMRT test at a $5 \%$ significance level. P0 = control, P1 = Organic fertilizer, P2 = Inorganic fertilizers, P3 = Mixed fertilizer, $11=$ Pottery irrigation, $12=$ Drip Irrigation, $13=75 \%$ ETc manual irrigation, $14=100 \%$ ETc manual irrigation

The early stages of plant growth require more water than other phases, and plants in the generative phase have a high rate of photosynthesis and low transpiration (Hidayati et al., 2016). By understanding the stages of the plant with each stage requirement for water. Liu et al. (2019) reported that water use efficiency was significantly affected by the plant growth stage, where soil moisture content was deficient in flowering and fruit set, fruit development, and fruit maturity stages.

The basic concept underlying drip irrigation is to keep a bulb of moist soil, thus, roots can absorb water adequately (Wang et al., 2011). Clay pot irrigation can improve soil structure by enhancing the efficiency of plant water use and soil organic carbon and improving soil fertility (Adhikary \& Pal, 2020). However, the pottery irrigation has various effects on the irrigated soil, and crop yield depends on the size of the pot. Irrigation water conservation by clay pot irrigation can be enhanced by altering the porosity by investigating the sand composition, wall thickness, and firing temperature. Fertilizer is one of the major factors influencing plant growth and yield. In general, plant growth increases by applying both organic and inorganic sources of mineral nutrition (Purbajanti et al., 2019).

The control treatment had the lowest plant height (56.67 $\mathrm{cm})$, significantly different from the other treatments. This is in line with Liu et al. (2020), which reported that the combined application of long-term organic and inorganic nitrogen fertilizers improves the physicochemical properties of the soil and increases the soil's organic carbon and nitrogen content. The weight of tomato fruit is associated with the macronutrients contained in the plant, especially P. Saputra et al. (2019) reported that $P$ and $K$ nutrients affected height, number of flowers, number of seeds per capsule, seed production, and germination energy and significantly affect the number of the leaf. Table 3, tomato fruit weight in P3 and P2 treatments was higher since the macronutrient was applied. Dewanto et al. (2017) reported that applying inorganic fertilizers could promote plant growth and increase green leaf formation, while a combination of NPK fertilizers can promote plant growth and increase plant growth biomass and increase productivity. The combined application of organic fertilizer, cattle manure, and biochar has advantages for better crop production (Zhang et al., 2020). The application of compost significantly increased $\mathrm{N}$ and $\mathrm{K}$ uptake and decreased soil $\mathrm{pH}, \mathrm{EC}$, and SAR, while increasing bulb yields of shallot (Rahayu, Saidi, et al., 2020; Syamsiyah et al., 2020).

The pottery irrigation can provide water to plants and result in a large number of fruits. This is in line with Adhikary and Pal (2020), which reported that clay pot irrigation improves soil physical properties, soil organic carbon, and water use efficiency. In addition, the nutrient content of soils influences the growth and development of plants, and adequate nutrients are needed in plant leaf control. In this study, mixed and inorganic fertilizers exerted higher effects on tomato yield than organic and control fertilizers. The application of nitrogen fertilizer with irrigation in clay pots improved the fertilizer use efficiency of tomatoes by up to $52 \%$. It was the best method for increasing the yield of tomatoes in a semiarid environment (Tesfaye et al., 2012). The dry weight of plants is interpreted as the content of plant organic matter in the form of biomass. 
Table 5. Comparison of mean volume of applied irrigation water under different irrigation techniques during the growth period of tomato.

\begin{tabular}{cccccccccccccc}
\hline & \multicolumn{10}{c}{ Treatment } & \multicolumn{1}{c}{ Irrigation volume (liter) } \\
\cline { 2 - 13 } & WK1 & WK2 & WK3 & WK4 & WK5 & WK6 & WK7 & WK8 & WK9 & WK10 & WK11 & WK12 \\
\hline I1P0 & $12.46 \mathrm{~b}$ & $7.28 \mathrm{~cd}$ & $11.48 \mathrm{~b}$ & $11.76 \mathrm{~b}$ & $7.00 \mathrm{c}$ & $17.36 \mathrm{ab}$ & $8.96 \mathrm{~cd}$ & $5.74 \mathrm{~d}$ & $8.68 \mathrm{c}$ & $6.44 \mathrm{de}$ & $11.48 \mathrm{c}$ & $11.76 \mathrm{c}$ \\
I1P1 & $5.97 \mathrm{e}$ & $5.88 \mathrm{de}$ & $5.69 \mathrm{c}$ & $6.35 \mathrm{~cd}$ & $8.21 \mathrm{c}$ & $9.43 \mathrm{c}$ & $10.13 \mathrm{~cd}$ & $14.09 \mathrm{c}$ & $9.89 \mathrm{c}$ & $10.03 \mathrm{c}$ & $5.69 \mathrm{~d}$ & $6.35 \mathrm{de}$ \\
I1P2 & $5.79 \mathrm{e}$ & $5.09 \mathrm{de}$ & $7.23 \mathrm{c}$ & $8.77 \mathrm{c}$ & $10.55 \mathrm{bc}$ & $10.22 \mathrm{c}$ & $11.20 \mathrm{c}$ & $10.50 \mathrm{~cd}$ & $8.77 \mathrm{c}$ & $8.68 \mathrm{~cd}$ & $7.56 \mathrm{~d}$ & $8.83 \mathrm{~d}$ \\
I1P3 & $4.48 \mathrm{f}$ & $3.41 \mathrm{e}$ & $4.29 \mathrm{c}$ & $5.64 \mathrm{~d}$ & $6.67 \mathrm{c}$ & $6.39 \mathrm{~d}$ & $7.37 \mathrm{~d}$ & $7.89 \mathrm{~d}$ & $7.00 \mathrm{c}$ & $5.46 \mathrm{e}$ & $4.29 \mathrm{~d}$ & $5.653 \mathrm{e}$ \\
I2 & $19.60 \mathrm{a}$ & $19.60 \mathrm{a}$ & $19.60 \mathrm{a}$ & $19.60 \mathrm{a}$ & $19.60 \mathrm{a}$ & $19.60 \mathrm{a}$ & $19.60 \mathrm{~b}$ & $19.60 \mathrm{~b}$ & $19.60 \mathrm{~b}$ & $19.60 \mathrm{~b}$ & $19.60 \mathrm{~b}$ & $19.60 \mathrm{~b}$ \\
I3 & $8.10 \mathrm{~d}$ & $9.00 \mathrm{c}$ & $13.30 \mathrm{~b}$ & $14.00 \mathrm{~b}$ & $14.00 \mathrm{~b}$ & $14.40 \mathrm{~b}$ & $18.70 \mathrm{~b}$ & $20.00 \mathrm{~b}$ & $20.00 \mathrm{~b}$ & $20.00 \mathrm{~b}$ & $19.90 \mathrm{~b}$ & $18.70 \mathrm{~b}$ \\
I4 & $10.90 \mathrm{c}$ & $12.00 \mathrm{~b}$ & $17.80 \mathrm{a}$ & $18.60 \mathrm{a}$ & $18.60 \mathrm{a}$ & $19.30 \mathrm{a}$ & $25.00 \mathrm{a}$ & $26.70 \mathrm{a}$ & $26.70 \mathrm{a}$ & $26.70 \mathrm{a}$ & $26.60 \mathrm{a}$ & $25.00 \mathrm{a}$ \\
\hline
\end{tabular}

Note: Means in a column followed by the same letters show no significant difference in the DMRT test at $5 \%$ level of significance. P0: Control (without fertilizer), P1: Organic fertilizer; P2: Inorganic fertilizers; P3: Mixed fertilizer; I1: Pottery irrigation; 12: Drip irrigation; 13: 75\% ETc manual irrigation; 14: 100\% ETc manual irrigation

The photosynthesis process runs smoothly when $\mathrm{P}$ and $\mathrm{K}$ nutrients are available. The water requirements of tomato plants need to be fulfilled with a proper and good irrigation system, and therefore the plants can grow optimally. Monte et al. (2013) reported that irrigation of more than $80 \%$ ETc promotes higher water usage without increasing the yield of tomato fruits.

\section{CONCLUSION}

In Alfisols, the pottery irrigation achieved the most efficient irrigation for growing tomatoes. At lower water usage in $75 \%$ ETc manual irrigation and drip irrigation, the pottery irrigation resulted in higher tomato yields than $75 \%$ ETc manual irrigation and a similar yield at $100 \%$ ETc manual irrigation. Drip irrigation and $75 \%$ manual irrigation showed the same yield production, while $75 \%$ ETc manual irrigation is more water-efficient than drip irrigation. Compared to organic and control fertilizers, mixed and inorganic fertilizers can significantly improve tomato yield. The use of the pottery irrigation with mixed or inorganic fertilizers resulted in a higher yield of potato fruit in Alfisols.

\section{Declaration of Competing Interest}

The authors declare no competing financial or personal interests that may appear and influence the work reported in this paper.

\section{References}

Abegunrin, T. P., Awe, G. O., Onofua, O. E., \& Ojediran, J. O. (2020). Effect of Supplemental Irrigation Interval and Mulching on Hydrothermal Properties of an Alfisol Cropped with Cucumis sativus. IOP Conference Series: Earth and Environmental Science, 445, 012019. https://doi.org/10.1088/1755-1315/445/1/012019

Abu-Zreig, M., Zraiqat, A., \& Elbaset, M. (2018). Seepage Rate from Ceramic Pitchers under Positive and Negative Hydraulic Head. Applied Engineering in Agriculture, 34, 707-714. https://doi.org/10.13031/aea.12813
Adhikary, R., \& Pal, A. (2020). Clay Pot Irrigation-A Review Study. Asian Plant Research Journal, 37-42. https://doi.org/10.9734/APRJ/2020/v5i130099

Ajiboye, G. A., Oyetunji, C. A., Mesele, S. A., \& Talbot, J. (2019). The Role of Soil Mineralogical Characteristics in Sustainable Soil Fertility Management: A Case Study of Some Tropical Alfisols in Nigeria. Communications in Soil Science and Plant Analysis, 50(3), 333-349. https://doi.org/10.1080/00103624.2018.1563100

Ariyanto, D. P., Komariah, K., Sumani, S., \& Setiawan, I. (2019). Actual Evapotranspiration Model Based on the Irrigation Volume of the Maize Fields on Alfisols. 2019, 16(1), https://doi.org/10.20961/stjssa.v16i1.25218

Cui, Y., Ning, S., Jin, J., Jiang, S., Zhou, Y., \& Wu, C. (2021). Quantitative Lasting Effects of Drought Stress at a Growth Stage on Soybean Evapotranspiration and Aboveground BIOMASS. Water, 13(1), 18. https://www.mdpi.com/2073-4441/13/1/18

Dewanto, F. G., Londok, J. J., Tuturoong, R. A., \& Kaunang, W. B. (2017). Pengaruh pemupukan anorganik dan organik terhadap produksi tanaman jagung sebagai sumber pakan. Zootec, 32(5). https://doi.org/10.35792/zot.32.5.2013.982

FAO. (1992). CROPWAT: a computer program for irrigation planning and management. Irrigation and Drainage Paper No. 46. Rome. https://www.fao.org/landwater/databases-and-software/cropwat/en/

Gebru, A. A., Araya, A., Habtu, S., Wolde-Georgis, T., Teka, D., \& Martorano, L. G. (2018). Evaluating water productivity of tomato, pepper and Swiss chard under clay pot and furrow irrigation technologies in semi-arid areas of northern Ethiopia. International Journal of Water, 12(1), 54-65. https://doi.org/10.1504/IJW.2018.10011180

Helyes, L., Bőcs, A., Lugasi, A., \& Pék, Z. (2012). Tomato antioxidants and yield as affected by different water supply. Acta Horticulturae 936, 213-218. https://doi.org/10.17660/ActaHortic.2012.936.25 
Hidayati, N., Triadiati, \& Anas, I. (2016). Photosynthesis and Transpiration Rates of Rice Cultivated Under the System of Rice Intensification and the Effects on Growth and Yield. HAYATI Journal of Biosciences, 23(2),

67-72. https://doi.org/10.1016/j.hjb.2016.06.002

Isah, A. S., Amans, E. B., Odion, E. C., \& Yusuf, A. A. (2014). Growth Rate and Yield of Two Tomato Varieties (Lycopersicon esculentum Mill) under Green Manure and NPK Fertilizer Rate Samaru Northern Guinea Savanna. International Journal of Agronomy, 2014, 932759. https://doi.org/10.1155/2014/932759

Jumawati, R., Sakya, A. T., \& Rahayu, M. (2014). Pertumbuhan Tomat pada Frekuensi Pengairan yang Berbeda. 2014, 16(1), 6. https://doi.org/10.20961/agsjpa.v16i1.18906

Leng, G., Leung, L. R., \& Huang, M. (2017). Significant impacts of irrigation water sources and methods on modeling irrigation effects in the ACME Land Model. Journal of Advances in Modeling Earth Systems, 9(3), 1665-1683. https://doi.org/10.1002/2016MS000885

Liu, J., Hu, T., Feng, P., Wang, L., \& Yang, S. (2019). Tomato yield and water use efficiency change with various soil moisture and potassium levels during different growth stages. PLOS ONE, 14(3), e0213643. https://doi.org/10.1371/journal.pone.0213643

Liu, L., Li, C., Zhu, S., Xu, Y., Li, H., Zheng, X., \& Shi, R. (2020). Combined Application of Organic and Inorganic Nitrogen Fertilizers Affects Soil Prokaryotic Communities Compositions. Agronomy, 10(1), 132. https://www.mdpi.com/2073-4395/10/1/132

Martínez, J., \& Reca, J. (2014). Water Use Efficiency of Surface Drip Irrigation versus an Alternative Subsurface Drip Irrigation Method. Journal of Irrigation and Drainage Engineering, 140(10), 04014030. https://doi.org/10.1061/(ASCE)IR.1943-4774.0000745

Monte, J. A., Carvalho, D. F. d., Medici, L. O., da Silva, L. D., \& Pimentel, C. (2013). Growth analysis and yield of tomato crop under different irrigation depths. Revista Brasileira de Engenharia Agrícola e Ambiental, 17(9), 926-931. 43662013000900003

Nabayi, A., Teh, C., Husni, M., \& Sulaiman, Z. (2018). Plant Growth, Nutrient Content and Water Use of Rubber (Hevea brasiliensis) Seedlings Grown using Root Trainers and Different Irrigation Systems. Pertanika Journal of Tropical Agricultural Science, 41(1). http://www.pertanika.upm.edu.my/pjtas/browse/reg ular-issue?article=JTAS-1090-2017

Pathak, P., Sudi, R., Wani, S. P., \& Sahrawat, K. L. (2013). Hydrological behavior of Alfisols and Vertisols in the semi-arid zone: Implications for soil and water management. Agricultural Water Management, 118, 12-21. https://doi.org/10.1016/j.agwat.2012.11.012

Phuntsho, S., Shon, H. K., Hong, S., Lee, S., \& Vigneswaran, S. (2011). A novel low energy fertilizer driven forward osmosis desalination for direct fertigation: Evaluating the performance of fertilizer draw solutions. Journal of Membrane Science, 375(1), 172-181. https://doi.org/10.1016/j.memsci.2011.03.038
Purbajanti, E. D., Slamet, W., Fuskhah, E., \& Rosyida. (2019). Effects of organic and inorganic fertilizers on growth, activity of nitrate reductase and chlorophyll contents of peanuts (Arachis hypogaea L.). IOP Conference Series: Earth and Environmental Science, 250, 012048. https://doi.org/10.1088/1755-1315/250/1/012048

Rahayu, Saidi, D., \& Herlambang, S. (2020). Pengaruh biochar tempurung kelapa dan pupuk kandang sapi terhadap sifat kimia tanah dan produksi tanaman sawi pada tanah pasir pantai. 2020, 10. https://doi.org/10.31315/jta.v16i2.3985

Rahayu, Syamsiyah, J., \& Sa'diyah, L. N. (2020). Aggregate stability of Alfisols root zone upon turfgrass treatment. 2020, $17(1)$, 7. https://doi.org/10.20961/stjssa.v17i1.40455

Saputra, A. S., Suprihati, \& Pudjihartati, E. (2019). The Effect of Phosphorus and Potassium on the Growth and Quality of Viola (Viola cornuta L.) Seed Production. 2019, 35(1),

11. https://doi.org/10.20961/carakatani.v35i1.33618

Somnuek, S., Hong, Y., Kim, M., Lee, S., Baek, J., Kwak, K., Lee, H., \& Lee, J. (2020). Assessment of Water Control Model for Tomato and Paprika in the Greenhouse Using the Penman-Monteith Model. Journal of BioEnvironment Control, 29(3), 209-218. https://doi.org/10.12791/KSBEC.2020.29.3.209

Syamsiyah, J., Herawati, A., \& Mujiyo. (2018). The potential of arbuscular mycorrhizal fungi application on aggregrate stability in alfisol soil. IOP Conference Series: Earth and Environmental Science, 142, 012045. https://doi.org/10.1088/1755-1315/142/1/012045

Syamsiyah, J., Rahayu, Herawati, A., \& Binafsihi, W. (2020). Study of levels water salinity on the growth of varieties of shallots (Allium ascalonicum L) in Alfisols. IOP Conference Series: Earth and Environmental Science, 423(1), 012065. https://doi.org/10.1088/1755$1315 / 423 / 1 / 012065$

Tesfaye, T., Tesfaye, K., \& Woldetsadik, K. (2012). Clay pot irrigation for tomato (Lycopersicon esculentum Mill) production in the north east semiarid region of Ethiopia. 2012, 112(1), 8. https://www.jarts.info/index.php/jarts/article/view/2 011101139325

Wang, R., Kang, Y., Wan, S., Hu, W., Liu, S., \& Liu, S. (2011). Salt distribution and the growth of cotton under different drip irrigation regimes in a saline area. Agricultural Water Management, 100(1), 58-69. https://doi.org/10.1016/j.agwat.2011.08.005

Xiukang, W., \& Yingying, X. (2016). Evaluation of the Effect of Irrigation and Fertilization by Drip Fertigation on Tomato Yield and Water Use Efficiency in Greenhouse. International Journal of Agronomy, 2016, 3961903. https://doi.org/10.1155/2016/3961903

Zhang, Z., Dong, X., Wang, S., \& Pu, X. (2020). Benefits of organic manure combined with biochar amendments to cotton root growth and yield under continuous cropping systems in Xinjiang, China. Scientific Reports, 10(1), 4718. https://doi.org/10.1038/s41598-020$61118-8$ 